\title{
Distance training for professionals in the Academia das Cidades and Academia de Saúde Programs in Pernambuco
}

\author{
Formação à distância para profissionais dos Programas Academia das Cidades e da \\ Saúde de Pernambuco
}

\section{AUTHOR'S \\ Emmanuelly Correia de Lemos ${ }^{1}$ (ID) Thassia Christina Azevedo da Silva ${ }^{2}$ (ID Neuza Buarque de Macêdo ${ }^{1}$ (D) Mateus Gustavo Brainer ${ }^{3}$ Sandra Luzia Barbosa de Souza ${ }^{2}$ (iD Célia Maria Borges da Silva Santana ${ }^{1}$ \\ 1 Escola de Governo em Saúde Pública de Pernambuco. Secretaria Estadual de Saúde de Pernambuco, Brasil. \\ 2 Gerência de Vigilância de Doenças e Agravos não Transmissíveis e Promoção da Saúde. Secretari Executiva de Vigilância em Saúde. Secretaria Estadual de Saúde de Pernambuco, Brasil. 3 Programa Academia da Cidade. Secretaria Municipal de Saúde do Recife, Pernambuco, Brasil.}

\section{CORRESPONDING}

Emmanuelly Correia de Lemos emmanuellylmeos@gmail.com

Rua Falcão, nº. 22, Ouro Preto, Olinda, Pernambuco, Brasil.

CEP: 53370-101.

DOI

$10.12820 /$ rbafs. $25 \mathrm{e} 0180$

\begin{abstract}
The objective of this study was to describe the experience of the development of the upgrading course in strategic actions for professionals in the Academia das Cidades e Saúde Programs, conducted by the School of Government in Public Health, together with the technical team of the Programs at the State Health Secretariat and the Secretariat for Urban Development and Housing, both from Pernambuco. For this, the experience report format was used. The course was developed through distance learning, in three stages: planning, development and evaluation. The minutes of meetings, tutors' reports, online course monitoring files and students' evaluations were used to describe the experience. The course was offered in 2019, in the state's first health macro-region. Of the 156 professionals enrolled in the course, and who worked in the Programs, 100 concluded it, and positively evaluated the course, mainly in terms of changes in their work practices.
\end{abstract}

Keywords: Primary health care; Health promotion; Permanent education; Health training and practices; Distance education.

\section{RESUMO}

O objetivo desse estudo foi descrever a experiência de desenvolvimento do curso de aperfeiçoamento em açôes estratégicas para profissionais dos programas Academia das Cidades e da Saúde, realizado pela Escola de Governo em Saúde Pública, em conjunto com a equipe técnica dos Programas na Secretaria Estadual de Saúde e na Secretaria de Desenvolvimento Urbano e Habitação, ambas de Pernambuco. Para isso, utilizou-se o formato de relato de experiência. O curso foi desenvolvido na modalidade a distância, em três etapas: planejamento, desenvolvimento e avaliação. Para descrição da experiência foram utilizadas as atas de reuniöes, os relatórios dos tutores, os arquivos online de monitoramento do curso e as avaliaçóes discentes. $O$ curso foi ofertado em 2019, na primeira macrorregião de saúde do Estado. Dos 156 profissionais matriculados no curso, e que atuavam nos Programas, 100 concluiram e avaliaram positivamente o curso, principalmente no que se refere as transformações em suas práticas de trabalbo.

Palavras-chave: Atenção primária à saúde; Promoção da saúde; Educação permanente; Formação e práticas de saúde; Educação à distância.

\section{(cc) BY}

This work is licensed under a Creative Commons Attribution 4.0 International License.

\section{Introduction}

The Academia das Cidades (PACID) and Academia da Saúde (PAS) Programs, implemented in $2007^{1}$ and in $2011^{2}$, respectively, have as their main objective to contribute to the promotion of the population's health, based on the requalification and / or construction of infrastructure hubs and qualified professionals to promote physical activities and other interventions that create opportunities to encourage healthy habits. Until the month of November 2019, Pernambuco had 340 hubs of these programs, distributed in 144 municipalities.

Some operational difficulties were identified in the municipalities (virtual and presential versions) by state monitoring ${ }^{3}$ in both Programs: Academia das Cidades and Academia da Saúde (PACID/PAS), among them: the development of interventions in the hubs of the programs that could reach children, adolescents and adult men; and the challenge of professionals to act in conjunction with the health care network in order to strengthen social control. 
Through this observation, the technical areas responsible for the State Programs sought to define a course of action that was within the structural, financial and operational reality of the aforementioned areas and, at the same time, contributed to solving and / or minimizing the difficulties reported by the professionals. To this end, it signed a partnership with the School of Government in Public Health of Pernambuco ${ }^{4}$ (ESPPE) due to its wide experience in the development of permanent education actions in health ${ }^{5,6}$ for workers in the Unified Health System.

In this context, an upgrading course in strategic actions for professionals from the Academia das Cidades and Academia da Saúde (PACID / PAS) Programs in Pernambuco was designed, with the objective of professional qualification in the PACID / PAS centers, through theoretical-practical reflections and the development of interventions aimed at overcoming the main difficulties faced in the operationalization of the programs, based on the guidelines of the National Health Promotion Policy ${ }^{7}$.

The teaching modality chosen for this course is emphasized: distance education, which is mediated by information and communication technology and developed through a virtual learning environment, common reality nowadays ${ }^{8}$. This option, at the same time, enabled the operationalization of the technical area, and allowed the access ${ }^{9}$ for the training processes to those professionals who work in municipalities far from larger urban centers, with heterogeneous employment contract and workload.

Thus, the objective of this paper was to describe the experience of the development of the upgrading training course in strategic actions for the professionals of the PACID / PAS Programs, which was carried out by ESPPE together with the technical team of the Programs at the State Health Secretariat and the Secretariat of Urban Development and Housing, both from Pernambuco.

\section{Method}

It is a descriptive study, of the experience report type, which allows the description and reflection on a certain phenomenon ${ }^{10}$. The experience was developed in Pernambuco, by the ESPPE technical team, the management of surveillance of non-communicable diseases and conditions and health promotion / Executive Secretariat for Health Surveillance (GVDANT-PS/ SEVS), of the expansion and qualification management of primary health care / Superintendence of
Primary Health Care (GEQAP/SAP), both from the State Health Secretariat (SES), and from the Urban Development and Housing Secretariat (SEDUH).

This manuscript shows the experience from the creation of the upgrading course in strategic actions for the professionals of the PACID / PAS programs, until its development in its first offer in 2019. This first offer included professionals working in municipalities of the first Health Macro-region, composed by I, II, III and XII Health Regions, which have their headquarters in Recife, Limoeiro, Palmares and Goiana, respectively. It is noteworthy that Pernambuco is organized territorially in 12 health regions, distributed in four Macroregions and, all of them will be covered in the course. However, considering that it is a new experience for everyone involved, it was decided to make one macro-region at a time, so that the successes could be enhanced, and the errors adjusted to each offer. To build the course, the following steps were performed:

1) Planning - systematic meetings between ESPPE, SEVS, SAP and SEDUH staff to: define the objectives of the course, the curricular organization and the structure of the remote course (course plan); mobilization of professionals who worked in the Programs and in the Support Centers for Family Health in different municipalities of Pernambuco to evaluate the course proposal and jointly build the lesson plans and the textbook of the course; creation of the visual identity and the Virtual Learning Environment (VLE) of the course, including educational tools; pacts for implementing the course in the collegiate instances of SUS (Health Unit System- Sistema Único de Saúde) management (Bipartite Intergovernmental Commission and Regional Intergovernmental Commission) with regard to the distribution of vacancies by municipality and financing; mobilization of the professionals of the Program for the enrollment in the course; and production of course material.

2) Development - opening of the course by class at the headquarters of the Health Regions; monitoring the course development at VLE; providing feedback on the course to teams in the Health Regions; conducting educational meetings with the tutors of the course; participation in the face-toface meetings of each axis of the course together with the tutors; carrying out an exhibition of experiences developed in the course. 
3) Evaluation - conducting online student learning assessment; conducting student learning assessment during face-to-face meetings on each axis; online assessment of the course by the students; conducting the course evaluation by the technical team and tutors during the pedagogical meetings; and conducting the evaluation at the final meeting of the course.

For the description of the experience, the minutes of meetings, tutors' reports, online files for monitoring the course in the VLE and student evaluations were used.

\section{Results and discussion}

The course was developed in the form of distance education, with a total workload of 210 hours, of which 30 hours were in person and 180 hours were remote, distributed over 25 weeks of learning. It was conducted through ESPPE's Virtual Learning Environment (VLE) and four face-to-face meetings, with one tutor for every 30 professionals. At VLE, discussions and distance activities were developed based on the themes covered in the course, including connection activities and the development of interventions that comprise the practical application of the contents worked on at the PACID/PAS.

The curricular matrix was structured in four axes - introduction to the course, knowing, analyzing and intervening, which addressed the following strategic themes: articulation with the health care network; development of activities for children; development of activities for adolescents; development of activities for men and social control in the poles of the Programs (Figure 1).

In each axis, weekly activities were conducted using the following educational resources: a) Awakening interest: composed of a short video recorded, produced by ESPPE, presenting testimony from a professional with experience in the theme to be worked on each week of learning; b) Sharing knowledge: it is a forum for the discussion of ideas, clarification of doubts, socialization of knowledge and issues seen during the weeks included in that axis; c) Textbook: didactic material with the content to be covered in the course and guidance on the week's activities; d) Fixing the content: online play activity that highlights some relevant aspects of the theme worked on each week; e) Connection activity: refers to the orientation of the practical activity that should be developed by the students at their workplace each week; f) Activity booklet: it is a wiki resource, similar to an online portfolio, in which the activities of the week would be recorded, in particular, the production of the connection activity and, finally, d) Student evaluation of the axis: questionnaire prepared with the objective of evaluating different aspects related to the course development.

At the end of each axis of the course, a face-to-

\begin{tabular}{|c|c|}
\hline Axix & Description \\
\hline Introduction to the Course & $\begin{array}{l}\text { In this axis, some essential were worked on to follow the course; they are transversal and articulate with the other } \\
\text { themes were addressed in the later axes. Guidance on the use of the virtual learning environment (VLE), milestones in } \\
\text { the construction of the SUS, key aspects of the National Policy for Primary Care and the National Policy for Health } \\
\text { Promotion, in addition to similar and different aspects between the various programs will be worked on, whether PACID } \\
\text { and / or PAS or similar. }\end{array}$ \\
\hline $\begin{array}{l}\text { Understanding } \\
\text { (diagnosis) }\end{array}$ & $\begin{array}{l}\text { The set of knowledge and practices developed in this axis was organized "get to know you". The articulating theme was to } \\
\text { know the place of social production of the population's health, offering to the professional the possibility of recognizing the } \\
\text { territory and its population; the structure and functioning of health services that serve this defined territory - the Unified } \\
\text { Health System; the role and place of health promotion actions in the hubs of the Academia das Cidades and Saúde } \\
\text { Programs in an integrated manner with other policies and programs. }\end{array}$ \\
\hline $\begin{array}{l}\text { Analysing } \\
\text { (planning) }\end{array}$ & $\begin{array}{l}\text { In this axis, the set of knowledge and practices developed in the previous axis organized to "analyze" is resumed. The } \\
\text { articulating theme was to analyze the health situation and living conditions of the population. It enabled the professional } \\
\text { to have a more complex articulation of knowledge to broaden his / her view of the socio-environmental reality, identifying } \\
\text { positive and / or negative singularities, based on the situations observed in the territory, always in an integrated way with } \\
\text { the other health policies and programs, allowing that an intervention proposal could be formulated. Thus, new knowledge, } \\
\text { techniques, practices and attitudes were added that allowed us to reflect and deepen the issues observed in the fields of } \\
\text { activity and their consequences. }\end{array}$ \\
\hline $\begin{array}{l}\text { Intervening } \\
\text { (results/ monitoring and } \\
\text { evaluation) }\end{array}$ & $\begin{array}{l}\text { The set of knowledge and practices developed here must was organized to "intervene". The articulating theme was } \\
\text { "Intervening on the population's health problems and needs". This axis prepared the professional to carry out promotion } \\
\text { actions (based on the planning from the previous axis, articulated with the contents covered in the course), monitoring } \\
\text { and evaluation. The activities of the axis were based on dialogic and communicative action, considering existing political } \\
\text { and social interests for the organization of interventions. }\end{array}$ \\
\hline
\end{tabular}

Figure 1 - Description of the axes of the improvement course in strategic actions for professionals in the academies of cities and health academy programs, Pernambuco, 2019.

Source: Pernambuco (2019) 


\section{ESPPE A Instituição - Cursos - Acervo - Secretaria Acadêmica - Editais}

4 Semana 4 - Política Nacional da Atenção Básica e Promoção da Saúde

\section{Semana 5 - Programas de Academia das Cidades (PACID) e da Saúde (PAS)}

Compartilhando Saberes - Introdução ao Curso

Na semana anterior, foram abordados os conteúdos referentes à Atenção Básica à Saúde e Promoção da Saúde; vocês tiveram a oportunidade de estudá-los e de conferir sua aplicação no território. Nesta semana, o foco será conhecer um pouco mais sobre o PACID e o PAS, desde sua regulamentação, semelhanças, especificidades à implantação em cada realidade local.

\section{Objetivos de aprendizagem}

1. Conhecer as principais características do PACID e do PAS

2. Analisar as publicações do PACID e do PAS

3. Compreender o processo de implantação do PACID e do PAS no município

Tópicos que serão abordados no texto

- Da regulamentação às especificidades do PACID e do PAS

- O PACID e o PAS a partir das publicações

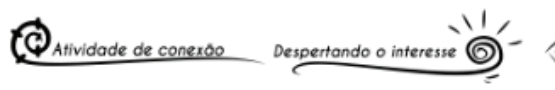
Caderno de texto 0
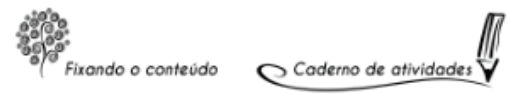

4 Semana 4 - Política Nacional da Atenção Básica e Promoção da Saúde

Figure 2 - Illustration of the virtual learning environment and the educational resources of the improvement course in strategic actions for professionals in the academies of cities and health academy programs, Pernambuco, 2019.

face meeting was held, with the objective of sharing the learning achieved at each moment of the course's development, as well as identifying the barriers and possible solutions for the development of the educational activities of the course. The meetings took place in the auditoriums of the headquarters of the Regional Health Offices.

The evaluation process of the course took place during the development of the proposed activities, taking into account the following criteria: performance; attendance; participation; criticality; ability to reflect on the context (in which the students were inserted as subjects acting in SUS); and participation in the proposed activities. These criteria were recorded in the System informed by ESPPE, exclusively by the tutor responsible for each class.

In the first offer of the course, six groups were formed for the health regions that make up the first health macro-region (metropolitan region of Recife). 156 professionals registered in the Academia das Cidades and / or Sauide Programs were enrolled in the municipalities of the mentioned health macro-region. Among those, 100 professionals finished the course. Of these,
$82 \%$ were Physical Education professionals. All the students produced interventions with the strategic themes of the course and these interventions pointed out that the course did contribute to the transformation of their professional practices. These changes can be observed in the reports indicated in the students' evaluations:

"It was an excellent opportunity to get to know different views on the same issues, to talk to professionals from other municipalities".

"It challenges us, as professionals, to leave the comfort of our functions and seek new knowledge and new ways of approaching different audiences".

"I found it truly relevant and satisfying. Especially when we see the examples of other hubs that already do what we thought, at some point, would be impossible to achieve.

"To know that the difficulties I experienced were not just mine, which served as a comfort and in parallel to know that if others succeeded, I would also be able to carry out the axis proposals"

"The introductory axis was fundamental both for adapting to the virtual environment and for re- 
vising the basic content, which is essential for the course as a whole".

"The contents covered in the analysis axis were useful for the deepening of knowledge and for the development of new strategies for working at the hub". "The intervening axis was important to put into practice what was discussed throughout the course, perceiving the possibilities and challenges of the proposals developed".

It was possible to verify that the objectives of the course were achieved. Nevertheless, it is important to note that there were many challenges experienced by everyone involved the course. Among these challenges, digital inclusion stands out, from the access to the equipment until its handling. Moreover, limitations on access to broadband internet, an aspect that is not a privilege of this course was also detected ${ }^{11}$. Another limitation was about the gaps related to the students' initial training regarding the SUS, which had to be explained or even resumed during the course. This is in line with the other findings ${ }^{12}$ which have indicated the distance between the under-graduation curricula (specially in Physical Education initial training) with the necessity of the SUS, and its performance specially focused on health promotion ${ }^{13}$. Added to this issue, the characteristics of distance education ${ }^{8,9}$ calls for an even greater need for self-organization related to the students' time management, and the development of interventions in their local reality.

The performance of the tutors of the course was very well evaluated by the students, however, it was identified by the technical team and by the tutors themselves, the need to qualify the pedagogical meetings to deepen the theoretical and practical aspects of the tutors' performance in distance education, and as educating agents, co-responsible for the social, cognitive and teaching presence ${ }^{14}$.

Another challenge was related to the ESPPE technical team of distance education, which needs to be better equipped with specialized professionals for the structuring and maintenance of the VLE, especially regarding the pedagogical aspects for this type of teaching as well as for the creation, editing and communication of the teaching materials.

Despite the challenges, it was an experience of great learning, due to the conception and objectives presented in the quadrilateral ${ }^{15}$ of health education, and also to the structuring of educational activities (based on the problematization of the work process), the experience managed to promote the change of professional practices and the (re)organization of the work process. Moreover, it also contributed to the promotion, welcoming, and caring for the various dimensions and the health needs of people.

\section{Conflict of interest statement}

The authors declare no conflict of interest.

\section{Authors' contributions}

Lemos EC, participated in the initial study design, data collection and analysis, writing and critical review of the text. Silva TCA, participated in the initial study design, data collection and analysis, writing and critical review of the text. Brainer MG, contributed to the initial study design, data analysis, writing and critical review of the text. Macêdo NB, was responsible for the literature search, data collection and critical text review. Souza SLB, participated in the literature search, data collection and critical text review. Santana CMBS, contributed to the literature search, data collection and critical text review. All authors approved the final version.

\section{Acknowledgment}

The authors would like to thank all and everyone involved in the construction and development of the course.

\section{References}

1. Pernambuco PCP. Decreto no 31.140 de 6 de dezembro de 2007. Institui o Programa Academia das Cidades no âmbito do Poder Executivo Estadual e dá outras providências. Diário Oficial de Pernambuco, Recife, PE, 07 dez. 2007. No 230, p. 3.2.

2. Brasil. Portaria GM/MS no 2.681, 7 de novembro de 2013. Redefine o Programa Academia da Saúde no âmbito do Sistema Único de Saúde (SUS). Diário Oficial [da] União. Brasília, p37, 8 nov 2013. Seção 1.

3. Lemos EC, Paes IMBS, Abath MB, Brainer MGF, Lima JIAF. Monitoramento do Programa

4. Academia das Cidades e da Saúde: a experiência de Pernambuco. Rev Bras Ativ Fís Saúde. 2015;20(2):203-7.

5. Pernambuco. Lei no 15.066 - Criação da Unidade Técnica Escola de Governo em Saúde - ESPPE - Diário Oficial [do] Estado [de] Pernambuco. Recife, 4 set 2013, p.5.

6. Pernambuco. Governo do Estado. Secretaria de Saúde. A educação como elemento transformador do trabalho em saúde: formação em saúde pública no SUS em Pernambuco. Recife: Editora Cromos; 2019.

7. Pernambuco. Governo do Estado de Pernambuco. Secretaria de Saúde. Plano de educação permanente em saúde de Pernambuco. Recife. 2018.

8. Brasil. Política Nacional de Promoção da Saúde. Portaria GM/MS no 2446, 11 de novembro de 2014. Diário Oficial [da] República Federativa do Brasil. Brasília, n. 220, p.68-70, 13 nov. 2014. Seção 1. 
9. Cruz JR, Lima DCP. Trajetória da educação a distância no Brasil: políticas, programas e ações nos últimos 40 anos. J. Polit. Educ. 2019;13(13): 1-19.

10. Batista MVV, Pinheiro CD. Contribuições para desmistificação da educação a distância. Revista de Pesquisa Interdisciplinar. 2019;4(1):4004-14.

11. Minayo MCS, Minayo-Gomez C. Difíceis e necessárias relações entre métodos quantitativos e qualitativos. (no prelo na Fiocruz, na coletânea organizada por Paulette Goldemberg). 2002.

12. Vargas FMA, Trindade MCN, Gouveia GDA. Farias MR. A educação a distância na qualificação de profissionais para o sistema único de saúde: meta estudo. Trab. Educ. Saúde. 2016;14(3):849-70.

13. Oiveira DCR, Brito ALS, Tassitano RM. Profile of professionals working in physical activity interventions within programs in the primary health care system in the State of Pernambuco. Rev Bras Ativ Fís Saúde. 2016;21(5):442-51.
14. Loch MR, Dias DF, Rech CR. Apontamentos para a atuação do Profissional de Educação Física na Atenção Básica à Saúde: um ensaio. Rev Bras Ativ Fís Saúde. 2019;24:1-5.

15. Dias FAO, Silva MAS. O uso das ferramentas na educação a distância e o papel do tutor. Rev. Psic. 2016;10(30):16-33.

16. Ceccim, RB, Feuerwerker LCM. O quadrilátero da formação para a área da saúde: ensino, gestão, atenção e controle social. Physis: Rev. Saúde Col. 2004;14(1):41-65.

Received: 30/06/2020

Approved: 01/02/2021

\section{Quote this article as:}

Lemos EC, Silva TCA, Macêdo NB, Brainer MG, Souza SLB, Santana CMBS. Distance training for professionals in the Academia das Cidades and Academia de Saúde Programs in Pernambuco. Rev Bras Ativ Fís Saúde. 2020;25:e0180. DOI: 10.12820/rbafs. 25e0180 